\title{
Article \\ The Evolution of Rural Tourism in Wuhan: Complexity and Adaptability
}

\author{
$\mathrm{Li} \mathrm{Lv}^{1,2}$, Jing Hu ${ }^{1, *}, \mathrm{Xin}_{\mathrm{Xu}}{ }^{1}$ and Xiaobo Tian ${ }^{1}$ \\ 1 The College of Urban and Environmental Science, Central China Normal University, Wuhan 430079, China; \\ lilv@mails.ccnu.edu.cn (L.L.); xxingeo@mails.ccnu.edu.cn (X.X.); txb3@mails.ccnu.edu.cn (X.T.) \\ 2 History Culture and Tourism College, Fuyang Normal University, Fuyang 236032, China \\ * Correspondence: huj@mail.ccnu.edu.cn
}

Citation: Lv, L.; Hu, J.; Xu, X.; Tian, $X$. The Evolution of Rural Tourism in Wuhan: Complexity and Adaptability. Sustainability 2021, 13, 13534. https:/ / doi.org/10.3390/su132413534

Academic Editors: Marko D. Petrović and Julia A. Syromiatnikova

Received: 3 November 2021

Accepted: 6 December 2021

Published: 7 December 2021

Publisher's Note: MDPI stays neutral with regard to jurisdictional claims in published maps and institutional affiliations.

Copyright: (c) 2021 by the authors. Licensee MDPI, Basel, Switzerland. This article is an open access article distributed under the terms and conditions of the Creative Commons Attribution (CC BY) license (https:// creativecommons.org/licenses/by/ $4.0 /)$.

\begin{abstract}
The complex adaptation system (CAS) theory of "adaptability to produce complexity" is a new theoretical perspective for the spatio-temporal evolution of rural tourism systems. Based on the CAS theory, the theoretical framework, structural composition, formation process, and evolution mechanism of the rural tourism complex system were examined and revealed. The suburban country region of Wuhan was taken as the area of focus for empirical research. The state of the rural tourism destination system in Wuhan has gone through various periods of development: the embryonic stage of the system (before 2000), formation (2001-2007), rapid development (2008-2015), and consolidation and transformation (since 2016). Under the environments stimulating external physical geography, social economy, market demand, and emergencies, multiple agents such as government, enterprises, residents, and tourists in Wuhan have actively adapted to the environment and other agents, and the interaction intensity and complexity have gradually increased, driving the emergence of system agent types, functional structures, and spatial patterns. The agents continue to grow, differentiate, and aggregate. The tourism product has shifted from the dominance of a rural ecological scenery and leisure agriculture to diversified development, and with the main function changing from sightseeing to leisure and vacation. The rural communities have been renovated and beautified, transforming them from a provider of rural service facilities to a co-builder of a rural-imaged tourism space.
\end{abstract}

Keywords: complex adaptive system (CAS); agents' adaptive behavior; rural tourism system; spatiotemporal evolution; Wuhan City

\section{Introduction}

With rapid advances and continuous improvements in urbanization, rural tourism is headed towards the worldwide economic, social, cultural, and environmental evolution of rural or community sustainable development [1]. Since the 1980s, China's rural tourism has experienced considerable development, and the rural tourism market has expanded rapidly [2]. In 2019, the number of rural tourism receptions in China reached 3.09 billion. With the implementation of the strategy of new urbanization and rural revitalization, the status of the rural tourism industry is increasing daily. It plays an important role in solving "rural issues", promoting the sustainable development of rural communities. Rural tourism has become a new element and new kinetic energy for rural revitalization and development $[3,4]$. Driven by socio-economic changes and national strategies, the flow of factors such as manpower, capital, information, and technology between urban and rural areas has been accelerated. New connotations, new features, and new rules in rural tourism market demand, business type, development mode, structure function, and spatial pattern have emerged [5,6], and the evolution of rural tourism systems has become more complex and adaptable [7,8].

The systematic evolution of tourism has always been an important field in tourism geography research [9], with Butler's life cycle theory being the most influential traditional theory on the evolution of the tourism destination system $[10,11]$. Although the TALC 
model is recognized as a useful framework for the description and interpretation of the evolution of tourism areas, both its applicability and theoretical approaches have been criticized [12]. Butler's TALC model fails to specify the differentiation between "tourism area" and "tourism product", and there is insufficient distinction between the confusing notions of "life cycle "and "evolution" [12]. In fact, the tourism destination is a complicated system containing all kinds of elements, which can be regarded as a coevolutionary process of tourism sectors, tourism products, and institutions occurring at multiple levels within a destination [12]. The spatial pattern, service facilities, product types, development mode, and functional benefits of the rural tourism system are constantly changing. Therefore, it is particularly important to comprehensively explore the evolutionary process, pattern, and mechanism of tourist destinations by using complex systematic thinking [10].

Complexity science is developed on the basis of system science. From Prigogine's dissipative structure theory and Haken's synergetic theory to Thom's catastrophe theory, then to chaos theory and fractal theory, it has experienced development from the context of a general system to a complex system, from cybernetics to self-organization and adaptability. Its scientific paradigm has gradually affected the development and research of the tourism system. Since the 1970s, scholars have started the research on the complexity of tourism destination systems [13]. The main research contents include the theoretical discussion of tourism complex systems [14,15], the reinterpretation of the life cycle of tourism destinations [16,17], the evolutionary process and mechanism of tourism destination systems [18,19], the planning and governance of scenic spots $[20,21]$, and the adaptive management of tourism destinations [22,23]. In conclusion, tourism complex systems and evolution studies are still in the pre-paradigm stage of different views and theoretical disputes [24], which encourage the theoretical study of complex systems of tourist destinations through principles such as the chaos theory [17], dissipative structure theory [25], self-organization theory [26], complex network theory [27], and complex adaptive system theory [28]. Tourism destination as a complex adaptive system has become a consensus [18,29], and the characteristics of the tourism system, such as nonlinearity, self-organization, imbalance, and chaos, have been fully discussed $[29,30]$. However, there is little research on the adaptive behavior of the system agents, the interaction between agents, the internal elements, and the external environment $[8,31]$.

Holland proposed the complex adaptive systems (CAS) theory in 1994. CAS emphasizes the subjective initiative of individuals, who can purposefully and directionally adjust their behavior and structure in order to achieve a good state of adaptation to the environment. The evolution of micro-subjects makes the macrosystem present a new state and structure, and the emergence of macrosystem "complexity" comes from the "adaptability" of micro-agents [32,33]. The term "complex" is used to describe a system in which interaction is detailed and where agents (people) make choices about their individual actions. A complex system is adaptive because it influences and is influenced by its environment [34]. The understanding of behavior patterns is viewed from the connections among diversity, conflict, and creativity within the system, which allows the capacity of spontaneous novelty or self-organization [29]. CAS is recognized as a third-generation system theory. Compared with first-generation system theories (represented by general system theory and cybernetics) and second-generation system theories (represented by dissipative structure theory and synergetic theory), the CAS theory has a comparative advantage $[35,36]$. It can play a key role in understanding and explaining the temporal evolution of tourist destinations over time. After being put forward, the theory is widely used in social and economic management fields such as urban development planning [37,38], enterprise management [39,40], industrial clustering [41], supply chains [42,43], ecological system $[44,45]$, and so on. The sufficient theoretical and case studies based on CAS provide a new theoretical perspective for the study of the evolutionary process and the mechanism of tourism destination complex systems. Although some scholars have analyzed the evolutionary processes of industrial cluster, rural human settlement environment, and tourism spatial pattern from the perspective of subject adaptation $[28,36,46]$, the research content 
is generally less, and the theoretical exploration and empirical analysis applied to rural tourism destination systems need to be further explored.

Hence, our main goal is to verify the adaptability of a complex adaptive system in explaining the evolution of rural tourism destination systems and to conduct a case analysis. To achieve our goals, this paper will include the following aspects: (1) A discussion of the element composition, complex characteristics, and generation mechanism of a rural tourism destination complex adaptive system. (2) Based on the CAS theory, we attempt to construct a theoretical framework for the "environmental state-agent adaption-system evolution" circular interaction of a rural tourism destination complex adaptive system. (3) We select Wuhan as a case for empirical analysis and analyze the environmental state, the adaptability of multiple subjects as well as the evolutionary characteristics of the development of the Wuhan rural tourism system in each period. It is hoped that our research can further enrich the theory of tourism destination system evolution and provide decision-making suggestions for the sustainable development of rural tourism destinations in Wuhan.

\section{Theoretical Analysis Framework}

\subsection{Overview of Complex Adaptive Systems Theory}

Complex adaptive systems (CAS) theory was proposed by John Holland in 1994 and mainly studies the mechanisms of a system's complexity and system emergence. The core of the theory is "adaptability produces complexity", and the adaptive interaction of microscopic agents can produce macroscopic complexity phenomena [33]. The theory believes that the system is a dynamic network composed of interacting and adaptable agents. Adaptive agents are capable of "learning" and "growing" in order to obtain the maximum symbiotic benefits [33]. Agents can adjust behavior rules to meet changes in the external environment and other agents' requirements in the process of interacting with the information, energy, and matter of the external environment. They move or aggregate to occupy a better niche and obtain the greatest benefits in symbiosis [33]. The overall differentiation, aggregation, and reconstruction of the system are gradually derived on the basis of the interactions between the agents and the environment [32]. Along with the dynamic adaptability process, the whole system leaps from chaos to order and from simple to complex [47].

The CAS theory puts forward two models: the basic behavior model of individual evolution and the echo model of overall evolution. Microscopically, to satisfy their own survival and development, adaptive agents follow the internal strategy model of "if-then" in their interaction with other agents and the external environment, and they constantly learn and accumulate experience to modify their own adaptive behavior. Multiple agents produce behavioral responses and adjustments with the process of "external environmentagents cognition-adaptive adjustment". Different levels of agents' learning or innovation ability lead to differences in the behavioral effects of the same type of agent (Figure 1).

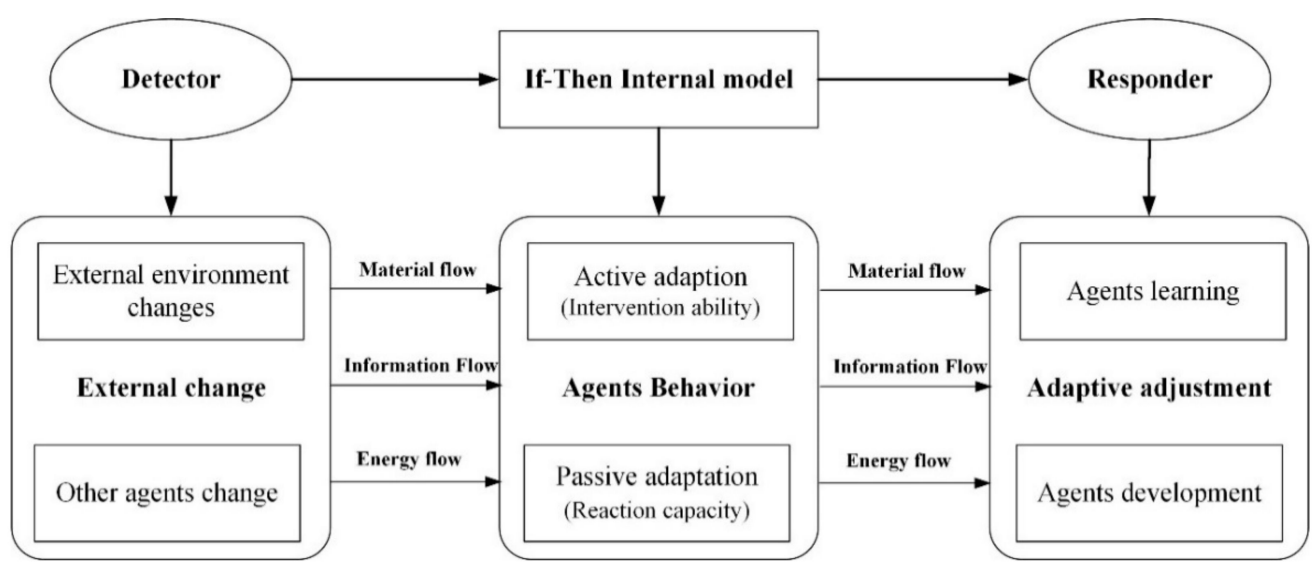

Figure 1. Behavioral model of adaptive agents. 
Macroscopically, the echo model of "agents-context-agents" is constructed to link individual evolution and system evolution. An echo is an agent-based, microsimulation model in which "agents" interact within a "site" located in a "world". The emergent behavior of the world is due to the interactions of the individual agents. The world provides a spatial and temporal context for agents that reside at specific sites [24]. Resources are the basis of system evolution, and location is the spatial place of the subject's activities. The world consists of several sites, and multiple agents are in different spatial sites that have a fountain with various experiences and resources, which constitute the basis of individual adaptability [33]. The ability to acquire resources from either site or other agents allows an agent to reproduce. Since the environment is continuously changing, new agent types evolve; thus, the patterns of exchange between agents will also evolve [24].

There are complex and diverse nonlinear interactions between agents and the environment, which affect the change of external environmental state and feedback to the behavioral response mode of agents, further promoting the process of the aggregation, diffusion, and reconstruction of the scale of spatial clusters and upgrading the overall evolution of the system layer by layer [33]. The internal structure of systems evolves, and cycles promote the emergence of the system. The macro system generates new elements, structures, and functions and evolves from one complex condition to another [32]. It is a "bottom-up" process arising when the collective behavior of interacting individuals results in a system or part of a system that adapts and creates an emergent order [34].

\subsection{Composition and Characteristics of the Rural Tourism Complex Adaptation System}

Holland characterizes seven basic elements of CAS. These seven characteristics consist of four properties-aggregation, nonlinearity, diversity, and flows, and three mechanismstagging, internal models, and building blocks [33] (Table 1). The rural tourism system is an open and complex giant system with chaotic characteristics and multiple subsystems. It is characterized by subjectivity, adaptability, self-organization, and dynamic balance [17,31], which agrees with the basic idea of the CAS theory [33] (Table 1).

Table 1. Compatibility analysis between rural tourism systems and main properties of the CAS theory.

\begin{tabular}{|c|c|c|}
\hline Element & Characteristic Interpretation & Compatibility Interpretation of Rural Tourism System \\
\hline Aggregation & $\begin{array}{l}\text { Aggregation of agents can form meta-agents, } \\
\text { and meta-agents are reaggregated to form } \\
\text { meta-meta-agents. The hierarchical } \\
\text { organization of CAS is formed, producing } \\
\text { complex phenomena. }\end{array}$ & $\begin{array}{l}\text { Rural agents are aggregated to different scales, types, and } \\
\text { levels of rural meta-agents such as tourism spots, tourism } \\
\text { facilities, and tourism communities, which constitute the } \\
\text { rural tourism system as subsystems. }\end{array}$ \\
\hline Tagging & $\begin{array}{l}\text { Different hierarchical systems have multiple } \\
\text { tags, which can not only promote the } \\
\text { "adhesion" of agents but also be used for the } \\
\text { "reproduction" of agents. }\end{array}$ & $\begin{array}{l}\text { Tourism image, core attractions, major projects, key policies, } \\
\text { etc., can all constitute tags, which promote the derivation, } \\
\text { differentiation, and gathering of villagers, citizens, } \\
\text { enterprises, and tourists. }\end{array}$ \\
\hline Flow & $\begin{array}{l}\text { Many nodes and connectors form a resource } \\
\text { flow network, and the cycle of resources has } \\
\text { a multiplier effect. }\end{array}$ & $\begin{array}{l}\text { Rural tourism destination system agents are connected with } \\
\text { each other and the external environment through passenger } \\
\text { flows, information flows, material flows, and capital flows. }\end{array}$ \\
\hline Nonlinearity & $\begin{array}{l}\text { The interaction between agents and } \\
\text { environment is nonlinear and promotes the } \\
\text { complex transition of the system. }\end{array}$ & $\begin{array}{l}\text { The rural system evolutionary process shows complex } \\
\text { evolutionary characteristics such as fluctuation, mutation, } \\
\text { and emergence, and new system agents, elements, } \\
\text { structural functions, and spatial patterns are apparent. }\end{array}$ \\
\hline Diversity & $\begin{array}{l}\text { Each new adaptation of agents opens up a } \\
\text { new ecological niche, promotes further } \\
\text { interaction, and thus brings about the } \\
\text { emergence of diversified systems. }\end{array}$ & $\begin{array}{l}\text { The continuous succession of external environment, tourism } \\
\text { demand, tourism supply, and participants promote the } \\
\text { formation of rural tourism with different modes, scales, } \\
\text { and functions. }\end{array}$ \\
\hline
\end{tabular}


Table 1. Cont.

\begin{tabular}{lll}
\hline \multicolumn{1}{c}{ Element } & \multicolumn{1}{c}{ Characteristic Interpretation } & \multicolumn{1}{c}{ Compatibility Interpretation of Rural Tourism System } \\
\hline $\begin{array}{l}\text { Internal } \\
\text { model }\end{array}$ & $\begin{array}{l}\text { Based on experience and learning ability, the } \\
\text { agents bitterly adapt to the perpetual novelty } \\
\text { environment and transform the adaptation } \\
\text { behaviors into an internal model to guide the } \\
\text { next adaptation. There are tacit and } \\
\text { overt models. }\end{array}$ & $\begin{array}{l}\text { In rural tourism, the tacit model is the choice of villagers' } \\
\text { livelihood strategy, enterprise management strategy, } \\
\text { government planning, and control, while the overt model is } \\
\text { the tourism product type and the spatial pattern of } \\
\text { rural tourism. }\end{array}$ \\
\hline Building blocks & $\begin{array}{l}\text { Blocks are coupled according to spatial } \\
\text { location and interactive action to build the } \\
\text { hierarchy and complexity of the system. The } \\
\text { higher-level rules are derived from the } \\
\text { lower-level building blocks. }\end{array}$ & $\begin{array}{l}\text { Rural tourism subsystems and elements constitute the } \\
\text { building blocks of high-hierarchy systems. The formation } \\
\text { and development, combination and dissolution, and } \\
\text { competition and cooperation of rural tourism "blocks" } \\
\text { reflect the evolutionary process of rural tourism. }\end{array}$ \\
\hline
\end{tabular}

According to the CAS theory, the rural tourism destination system is divided into tourist attractions, tourist facilities, rural tourism community multiagent, and external environment systems (Figure 2). Under the co-interaction of the self-organization of multiple agents and other organizations in the external environment, the five subsystems are interrelated, and through the exchange of material, energy, and information, an orderly rise in the development level of the rural tourism system and the dynamic optimization of the spatial agglomeration pattern are realized.

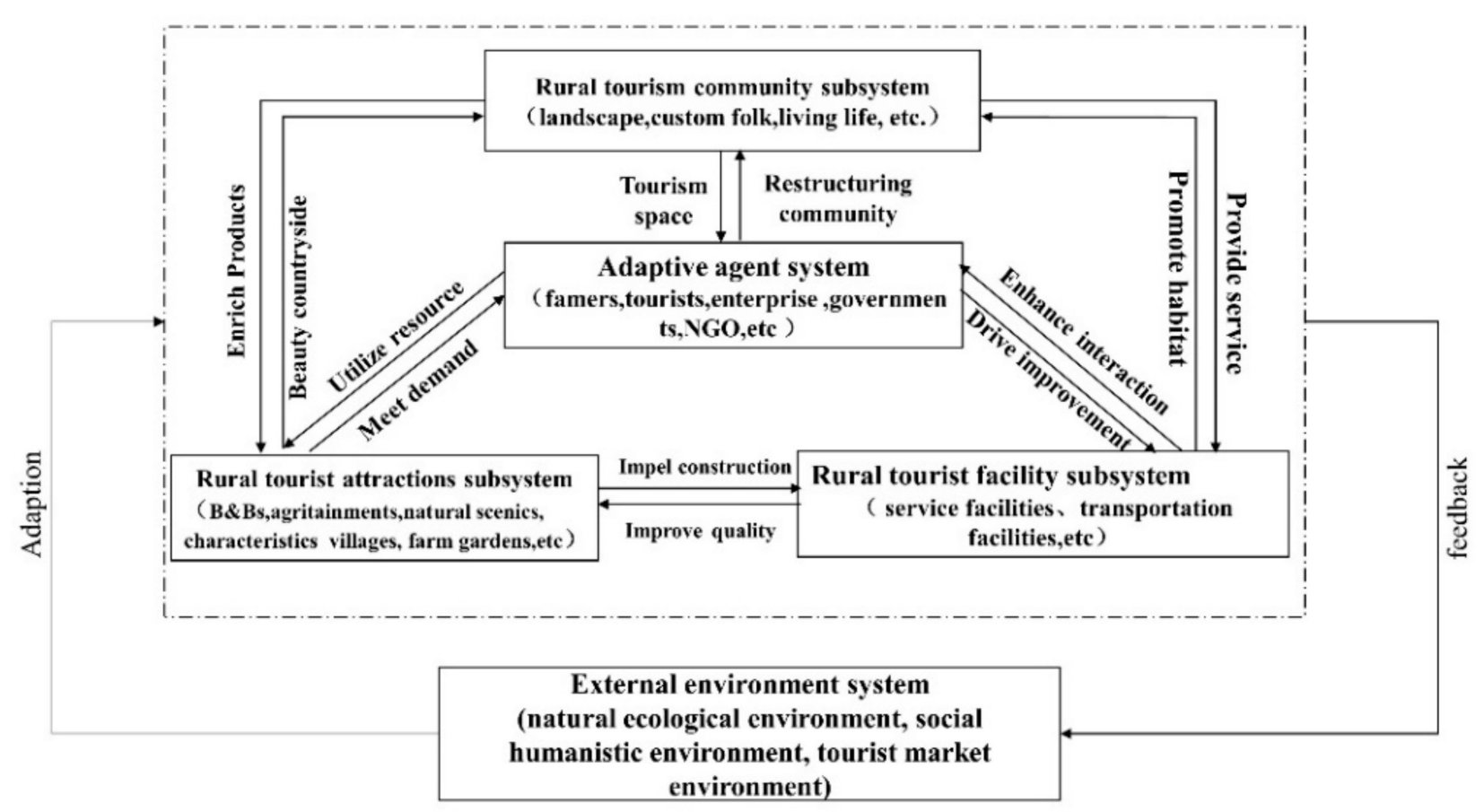

Figure 2. Composition of a complex adaptation system in a rural tourism destination.

The core attraction or the tourism image tags guides the government, enterprises, villagers, tourists, and other agents to execute the "internal model" according to their own "resource pool" in order to generate adaptive behavior to match other adaptive agents and the external environment, etc.; this promotes the generation, development, and spatial agglomeration of "building blocks" such as diversified rural tourism attractions, tourism facilities, and multiple agents. There is a "nonlinear" development in the aggregation process of agents and the transmission process of element flows, and the "nonlinear" interaction process promotes the emergence of rural tourism product types, spatial states, and functional structures [48] (Table 1). 


\subsection{Complex Adaptive Mechanism of Evolution of Rural Tourism}

On the microlevel, multiple agents detect environmental conditions and engage in adaptive behaviors. Under the disturbance of the natural geographical environment, socioeconomic environment, market demand environment, and other unexpected events, villagers, government, enterprises, tourists, and other agents actively adapt to the environment and show different behavioral patterns (Figure 3). At the same time, to coexist in a better system, agents can correct the behavioral pattern according to the behavioral effect [46]. In the process of adaptation, agents interact with each other and gather in rural areas with beautiful environments, perfect facilities, and prominent locations, forming a number of rural tourism spatial clusters [28].

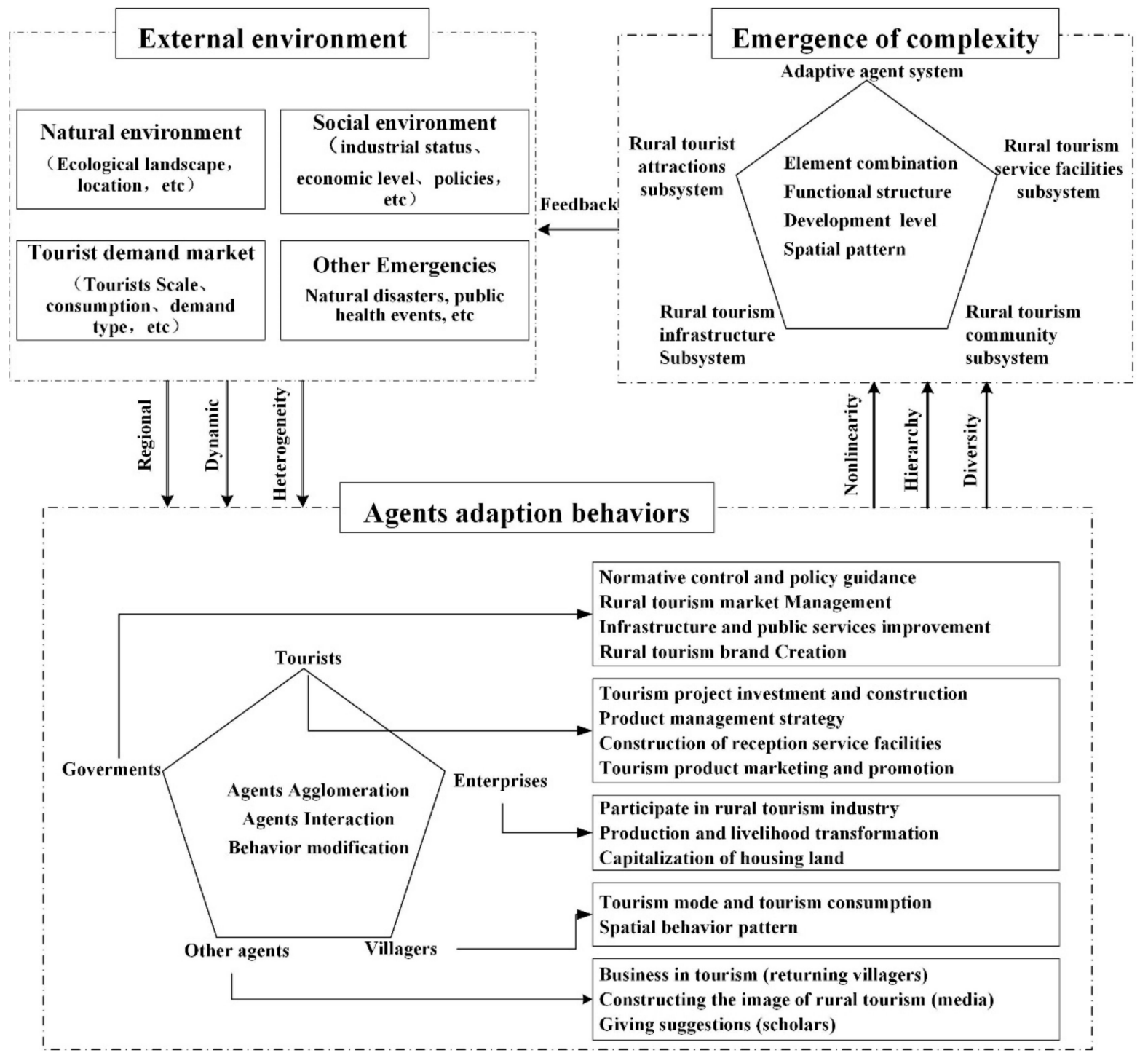

Figure 3. Adaptive behavior and echo model of multiple agents in a rural tourism destination system.

On the macro level, the adaptive behavior of the agent promotes the complex evolution of the system. First, when the external environment changes, diversified adaptation strategies and degrees are shown by agents with differences in statistical characteristics, learning ability, and resources [36], which influence the direction and speed of the evolution of the rural tourism system. Second, there are nonlinear interactions between agents and the environment. The evolution of the rural tourism destination system is characterized by "short-term oscillation", "long-term cycle", "fluctuation and bifurcation", and other 
development processes [49]. Finally, the spatial agglomeration of agents has different levels such as the scenic area scale, village scale, town scale, and county scale. The spatial agglomeration of agents at a lower level constitutes a spatial agglomeration at a higher level as "building blocks". The higher levels of rural tourism development and spatial pattern are derived from the low-level subsystems. When the individual behavior strategy changes dynamically, it will affect the overall structure and function of the rural tourism system step by step [33]. The diversity, nonlinearity, and hierarchy of the agents' response processes promote the complex evolution of the rural tourism destination system. New elements, functional structures, development levels, and spatial patterns emerge [50], which are fed back to the external environment, and the agents further revise the adaptation strategy and behavioral response, thus promoting the formation of more complex agent behaviors (Figure 3).

The cyclic process of "environmental state-agent adaptation-system evolutionenvironmental feedback" promotes the spiral development of rural tourism destination systems. As the level of the national economy and transportation improves, the element flow scale expands, multiple agents interact frequently, and the number, scale, and quality of rural tourism increase. More agents participate in the development of the rural tourism industry, which drives the orderly development of the rural tourism destination system and the dynamic optimization of spatial patterns.

\section{Case Location and Data Sources}

\subsection{Case Location}

Wuhan, located in eastern Hubei Province, is the core city of the Yangtze River Economic Belt (Figure 4). The terrain is high in the north and low in the south, with numerous wetlands and lakes and a good ecological environment. In 2020, the resident population of Wuhan was 12.327 million, and the city's regional GDP was CNY 1561.606 billion. The six administrative districts of Huangpi, Caidian, Xinzhou, Dongxihu, Jiangxia, and Hannan under Wuhan are mostly comprised of rural areas, which is the research focus of this paper. In 2020, there were 32 scenic spots above Grade 3A in the rural areas of Wuhan, accounting for $60 \%$ of the total number of destinations in Wuhan. The vast tourist market, excellent ecological environment, and profound farming culture have promoted the rapid development of the rural tourism industry in Wuhan. Since the reform and opening up, followed by the tide of rural tourism development in China, the rural tourism industry in Wuhan has been progressing step by step, reflecting the law of rural tourism to a certain extent.

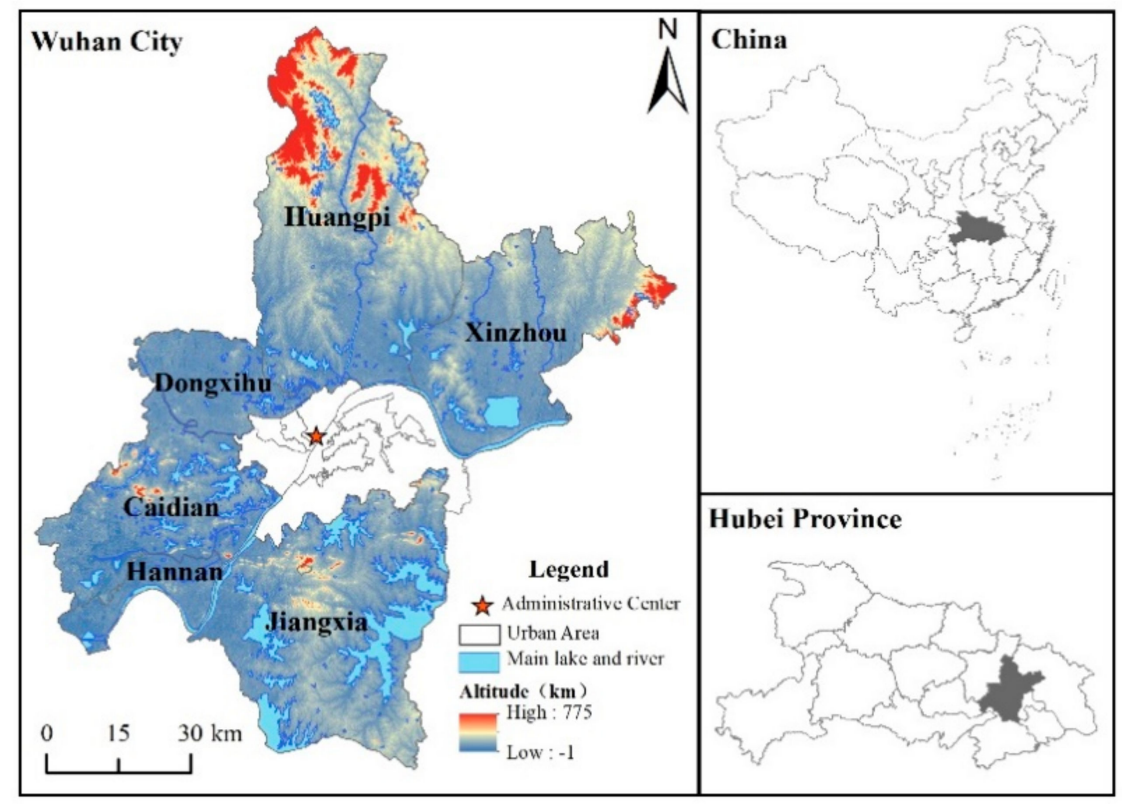

Figure 4. Location of the Wuhan countryside area. 
In 2000, rural tourism in Wuhan started and has since developed rapidly. In 2020, the number of rural tourists reached 57.18 million, the total tourism revenue reached CNY 20.843 billion, and there were 3562 rural leisure tourism business units of various types (Figure 5). There are 32 scenic spots above grade $3 \mathrm{~A}$ in the rural areas of Wuhan, accounting for $60 \%$ of the total destinations in Wuhan (Table 2).
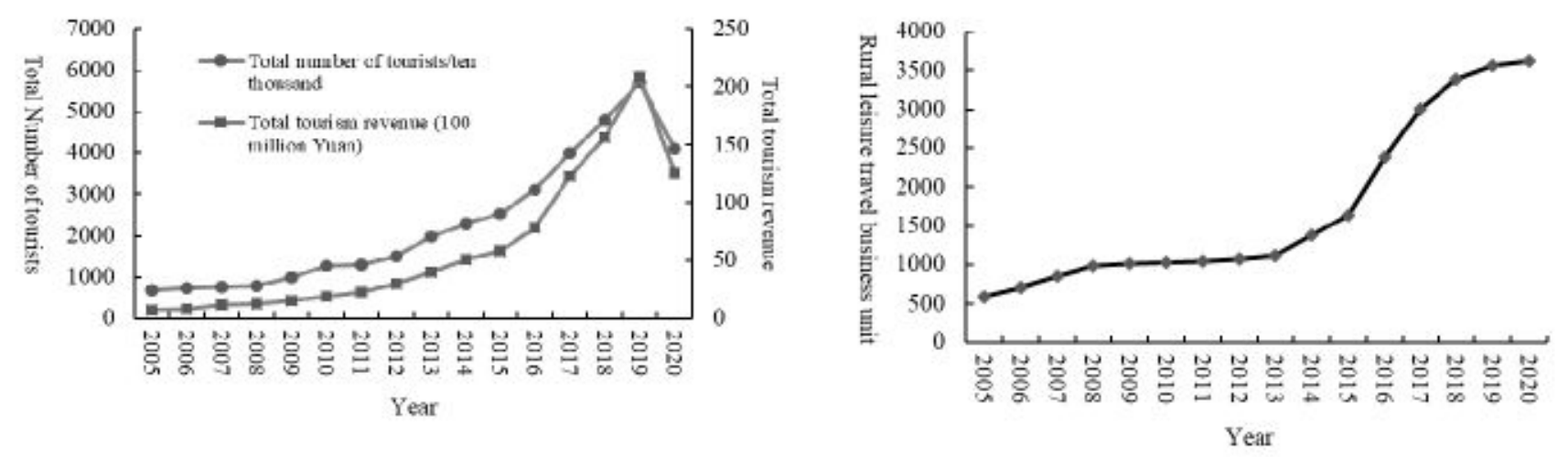

Figure 5. Total number of rural tourism income, tourists, and business units in Wuhan since 2005.

Table 2. Changes in the number of well-known tourist attractions in Wuhan.

\begin{tabular}{ccccccccc}
\hline Year & $\begin{array}{c}\text { National } \\
\text { 3A Scenic } \\
\text { Spot }\end{array}$ & $\begin{array}{c}\text { National } \\
\text { 4A Scenic } \\
\text { Spot }\end{array}$ & $\begin{array}{c}\text { National } \\
\text { 5A Scenic } \\
\text { Spot }\end{array}$ & $\begin{array}{c}\text { Provincial Leisure } \\
\text { Agriculture } \\
\text { Demonstration Spot }\end{array}$ & $\begin{array}{c}\text { Provincial } \\
\text { Tourism } \\
\text { Village }\end{array}$ & $\begin{array}{c}\text { National } \\
\text { Culture Relic } \\
\text { Protection site }\end{array}$ & $\begin{array}{c}\text { Municipal } \\
\text { Three-Star } \\
\text { Homestay }\end{array}$ & $\begin{array}{c}\text { Municipal RV } \\
\text { Campground }\end{array}$ \\
\hline 2000 & 1 & 0 & 0 & 0 & 0 & 1 & 0 & 0 \\
2007 & 1 & 0 & 4 & 5 & 2 & 16 & 0 & 0 \\
2015 & 11 & 6 & 4 & 5 & 10 & 30 & 0 & 0 \\
2020 & 14 & 14 & 4 & 19 & & 3 & 44 & 11 \\
\hline
\end{tabular}

\subsection{Data Sources}

The research data come from a field investigation and historical materials. In the field investigation, from April to June 2021, the research group visited 15 famous rural tourism villages selected by Wuhan. The first batch of 25 municipal-level rural tourism villages were voted by the Wuhan Culture and Tourism Bureau in 2020. Based on the rural tourism development pattern, development level, and the regional difference, we chose 15 tourism villages to visit and observe in order to obtain a macroscopic understanding of the characteristics of rural tourism development in Wuhan. In addition, questionnaires and in-depth interviews were conducted among various rural tourism participants, such as ordinary villagers, village cadres, farm operators, and managers of scenic spots, in order to understand the development process, development mode, participation process, and policy support of rural tourism. Detailed information on the questionnaire and the interview outline can be obtained from the appendix. The historical materials about villages, transportation, and tourism are the major data sources, mainly extracted from the Wuhan Yearbook, Wuhan Statistical Yearbook, Wuhan Municipal Government Work Report, etc., and academic literature on rural tourism in Wuhan.

\section{Evolutionary Process and Spatial Pattern of Rural Tourism Destination System in Wuhan}

\subsection{Effects of Multiple Agents' Behaviors and Rural Tourism System Development in Wuhan}

According to the rural tourism evolution framework of "environmental state-agent adaptation-system evolution", the development process of rural tourism destination in Wuhan is divided into four stages according to factors such as interaction complexity among multiple agents, the important events leading to the abrupt change in the rural tourism destination system, and the development characteristics of rural tourism destination system. We tease out the self-adaptive behavior of the government, villagers, 
enterprises, tourists, and other subjects under the influence of the external environment of the natural environment, social economy, market demand, and emergencies as well as the characteristics of the co-evolution of the system.

\subsubsection{Embryonic Stage of the Rural Tourism System (before 2000)}

With the establishment of ecological concepts and sustainable development concepts, people began to yearn to return to nature, and tourism development gradually tilted toward the suburbs. Around Mulan Lake, Mulan Mountain, Zhiyin Lake, Liangzi Lake, Daoguan Lake, and other surrounding areas, a number of cadre sanitariums, training centers, resorts, and leisure villas with conference and holiday functions have been built and scattered [51]. The construction and development of tourist resorts transformed Wuhan tourism from a transit destination to a sightseeing and leisure destination and promoted the inward development of Wuhan tourism (Table 3).

Table 3. Multiple agents' behaviors in the embryonic stage of the rural tourism destination system.

\begin{tabular}{ll}
\hline Agent & Adaptive Behaviors \\
\hline Government & In 1995, the "Ninth Five-Year Plan" put forward the development \\
plan of building several holiday resorts around the city. \\
Enterprise & Enterprises and institutions built resorts around lakes and mountains. \\
Visitor & Some travel companies operated and launched one-day tour routes. \\
\hline
\end{tabular}

At this time, the low-level social and economic environment had difficulty supporting large-scale tourism activities, and the rural tourism destination system had not yet formed. The tourism attraction system relied on the original natural and religious cultural resource endowment and lacked scenic spots that had been created actively. Rural tourism products were unconnected and had no system at all, with accommodation, vacation, and conference products as the leading factors. Its main clients were conference tourists organized by government organizations, enterprises, and institutions, with few individual tourists. Infrastructure, reception facilities, and other facility subsystems were not yet sound. The villagers prioritized agricultural production, and the rural communities maintained the original landscape pattern. The development of the tourism system was mainly led by the government, and interaction among multiple agents was limited (Table 3).

\subsubsection{System Formation Stage of the Rural Tourism System (2001-2007)}

During this period, the external environment of the rural tourism destination system in Wuhan greatly improved, and the status and role of the rural tourism industry received attention. With the increasing social and economic level accompanied by the Golden Week holiday system, Wuhan urban residents increased their leisure time and their willingness to travel (Figure 5).

To promote the standardization and development of the rural tourism industry in Wuhan, the government agents issued tourism planning and rural leisure travel notices, and formulated the rating standard of agritainment (Table 4 ). At the same time, government agents actively improved the rural tourism infrastructure and reception facilities; every township had access to oil roads, and villages had access to highways. The construction of important tourist traffic roads and expressways around the city were completed to promote the increase of passenger and information flows between urban and rural areas. These response behaviors promoted the optimization of the spatial distribution of the "building blocks" of rural tourism elements, improved the rural tourism development environment, and enhanced the convenient interaction of other agents.

Innovating on the development mode of scenic spots, the mode of "state ownership, government planning, and enterprise management" optimized the "internal model" of scenic spot management (Table 4). Tourism enterprises became dominant in this period, and the completion and opening of the Mulan Heaven Lake marked the prelude of rural tourism construction in Wuhan. The "Mulan cultural tourism image" had played a tagging 
function of the "reproduction" and "aggregation" of various tourism scenes. The scale and demonstration effect brought by the Mulan series of scenic spots established Huangpi District's leading position in Wuhan. In addition, leisure agriculture started, and several agricultural tourism demonstration sites were created, but the scale effect was not obvious.

Table 4. Multiple agents' behaviors in the formation stage the of rural tourism system.

\begin{tabular}{cl}
\hline Agent & \multicolumn{1}{c}{ Adaptive Behaviors } \\
\hline & The Wuhan Tourism Master Plan and Mulan Eco-tourism Area Plan were issued and implemented. \\
"Quality Classification and Evaluation of Leisure Farmhouses" was formulated. Rural tourism \\
associations, tourism websites, and government departments were established. \\
The "ring-radial shaped" network road were built. \\
In 2005, the "Home Construction Action Plan" was launched to renovate the country environment. \\
Enterprise & Since 2002, "Mulan series scenic spots" in Huangpi District have been opened one after another. \\
Resident & Residents set up hotels, agritainments. \\
Visitor & Increase in tourist scale. \\
\hline
\end{tabular}

Pioneering farmers and rural elites paid attention to the income opportunities brought about by the increase in passenger flow scale and actively participated in the development of the tourism industry. The process of tourism commercialization enriches the supply of rural tourism attractions and tourism facilities. With the opportunity for new rural construction, some villages were gradually transformed into professional tourism villages. Taking Shiliuhong village as a typical example, it became the core tag derived from the cluster, which had an obvious demonstration driving effect.

On the whole, under the influence of the external environment, enterprises, government, residents, tourists, and other multi-agents responded positively during this period, and the interaction between multi-agents and the external environment was enhanced (Figure 3), which jointly promoted the tourism industry system dominated by rural ecological sightseeing and supplemented by rural cuisine, farming activities, and folk customs. The rural tourist destination system was initiated, and the overall effect of the system became apparent (Table 4).

\subsubsection{Rapid Development Stage of the Rural Tourism System (2008-2015)}

During this period, the external environment of the rural tourism system was greatly improved. Firstly, the construction of an ecological civilization was promoted. A green ecological network system of "one circle, three rings, and six wedges" was built in Wuhan, creating many ecological spaces such as forest parks, wetland parks, country parks, ecological villages, and greenways around lakes and mountains. Secondly, the urbanization process in Wuhan was accelerating, and the transformation of consumer demand drove the supply-side reform of the tourism industry, while the status of rural tourism as an important supplement was gradually improved. Finally, with the continuous improvement of infrastructure and the improvement of the national economic level, the rural leisure consumption demand in Wuhan increased daily (Figure 5). The renewal of the external environment increased the number of adaptive agents in the rural tourism system significantly, all kinds of tags accelerated the flow of concentrated elements, and the nonlinear interaction between multiple agents and the external environment was further enhanced.

The government responded positively and improved the development environment of rural tourism, optimizing the "internal model" of system element combination. The government issued policies and plans to promote the moderate-scale operation and the intensive and diverse utilization of land and laid a spatial foundation for rural tourism. It promoted the emergence of a large number of tourist destinations such as flower viewing spots and agricultural landscape parks (Table 5). In addition, government agents continued to improve tourism infrastructure and tourist reception facilities, build the Wuhan onehour traffic circle, and further improve the tourism transportation network, urban-rural expressways, and rural village trunk roads. The accessibility of scenic spots and rural 
areas was enhanced, and the diffusion effect of the tourism industry was obvious, which promoted the scale of passenger flows and the growth of tourism spatial clusters.

Table 5. Effects of multiple agents' behaviors in the rapid development stage of the rural tourism system.

\begin{tabular}{|c|c|}
\hline Agent & Adaptive Behaviors \\
\hline Government & $\begin{array}{l}\text { Since 2008, Opinions on Accelerating Rural Land Circulation and Agricultural Scale Management, } \\
\text { Developing Farmhouse Tourism have been issued. } \\
\text { In 2012, "Wuhan Flower Tour Development Plan" established Wuhan as a "new flower city" and built six } \\
\text { pastoral landscape flower viewing areas; } \\
\text { In 2014, the "Mulan Culture Ecological Zone", a national 5A scenic spot, was built; the Mulan legend was } \\
\text { approved as a national intangible cultural heritage. } \\
\text { The tourism road network was further improved; a Wuhan scenic spot annual card was issued. }\end{array}$ \\
\hline Enterprise & $\begin{array}{l}\text { Scenic spots such as Yunwu Mountain, Jinli Valley, Yao Mountain, and Houguan Lake were built, and } \\
\text { Jiuzhen Mountain, Dayu Bay Village, and Qingliang Village were rated as national 4A tourism spots. } \\
\text { Lianghu Farm, Jinlong Water Village, Tulip Park, Mulan Rose Garden, Crape Myrtle Urban Garden, etc. } \\
\text { were opened one after another. }\end{array}$ \\
\hline Resident & $\begin{array}{l}\text { More villagers began to consciously carry out tourism business activities and resorts, family farmhouses, } \\
\text { agritainment, and produce sales increased significantly. } \\
\text { Farmers transferred the idle land to agricultural companies and tourism cooperatives, etc. }\end{array}$ \\
\hline Visitor & $\begin{array}{l}\text { The scale of passenger flows increased significantly, and self-driving tours and rural vacations had become } \\
\text { the mainstream. } \\
\text { Tourists looked forward to the "authentic" rural landscape and lifestyle. }\end{array}$ \\
\hline
\end{tabular}

The favorable policy environment and the growth of passenger flows stimulated the adaptive behavior of tourism enterprises, and the number of rural tourist destinations increased significantly, which were developed toward branding (Table 5). In 2015, Mulan Grassland, Mulan Heaven Lake, Mulan Cool Village, and Yunwu Mountain were integrated to create the national 5A-level scenic spot called the Mulan Eco-cultural Tourism Zone, which further strengthened the "Mulan" identification and significantly enhanced the tourism status of Huangpi District. Similarly, high-grade scenic spots for the "tag" were established in the Caidian District, Jiangxia District, and Dongxihu District to attract more tourists, enterprises, and villagers to grow and gather and promote the formation of rural tourism plates. The rural tourism industry system was further improved. The construction of ecological scenic spots was steadily advanced, and leisure agriculture demonstration spots developed rapidly and became the leading rural tourist destination in this period.

With the demonstration of pioneer farmers and the encouragement of the government, community residents began to consciously carry out tourism business activities, and the number of registered agritainments increased significantly (Table 5). To meet the high demands of tourists for rural service facilities and those of the ecological environment, the government launched the second round of new rural construction of hardening rural roads, renovating damaged toilets, collecting rural sewage, and sorting household garbage to improve the living environment and shore up ecological weaknesses. There was a focus on the construction of Baiquan new town and the "Auspicious Four Seasons" homeland along national highway 318 in Caidian, 107 in Jiangxia, and other new rural demonstration areas (Figure 6). The coordinated development of the rural tourism industry and the new rural construction transformed part of the countryside from being farmers' production and living spaces into tourists' consumption spaces. There were four tourism transformation village types: whole village tourism type, scenic driving type, rural elite driving type, and enterprise driving type [52] (Table 6).

On the whole, the complex changes of the external industrial environment, economic environment, and tourists' demands promoted the positive response of multiple agents, further enhanced the interaction, and improved the rural tourism system in an orderly manner (Figure 3). Favorable policies have led to the acceleration of the flows of agglomeration elements and the emergence of a large number of agricultural and leisure tourist 
destinations. The trend of non-agriculturalization of the rural industry was obvious, the infrastructure and living environment improved, and the rural community was gradually transformed into a tourism consumption space with rural tourism attractions.

(a) Embryonic stage

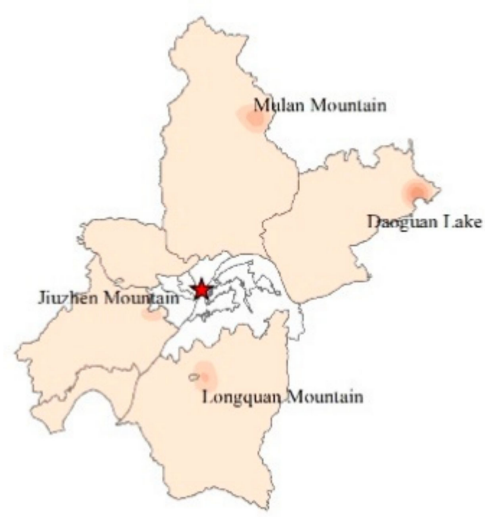

(c) Development stage

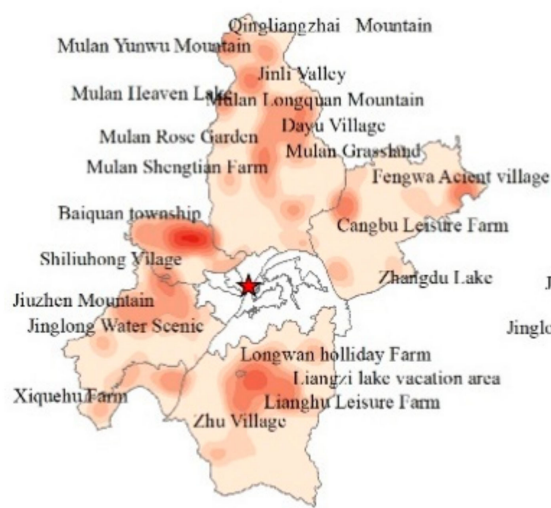

Spatial Density $\left(\mathrm{PCS} / 100 \mathbf{k m}^{2}\right)$ (b) Formation stage

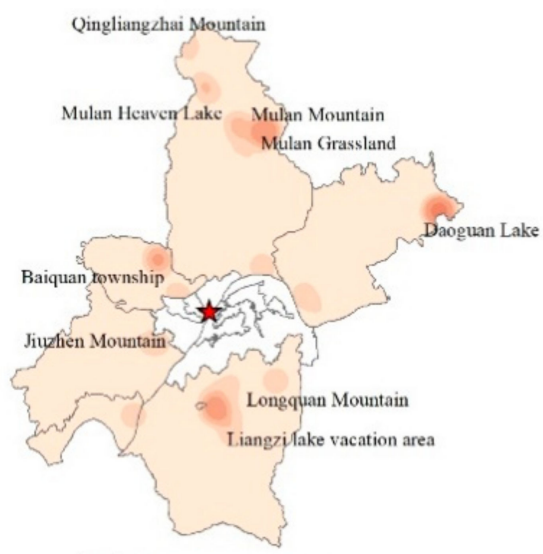

(d) Transition stage Qingliang/hai Mountain

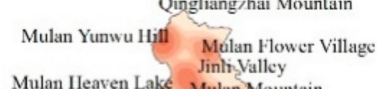

Mulan Heaven Lake Jinli Valley

Mulan Rose Garden Dayu Village

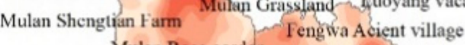

Mulan Rose garden
Lagerstrocmia 1jann Garden

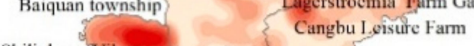

Shiliuhong $X_{i}$

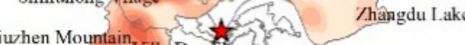

when Mountain Ville Bes fecus?

glong Water Scenic Thanxing vacaiton yillage

Thu Village Liangzi lake vacation area

Xiquelíy Tarm Tianghu I.eisure Farm

Haiyang vacaiton village

Lhoyuan vacaiton village

Lus

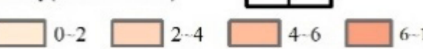

Figure 6. Rural tourism spatial agglomeration pattern of different periods in Wuhan.

Table 6. Development model of rural tourism in Wuhan during the rapid development period.

\begin{tabular}{|c|c|c|c|c|}
\hline $\begin{array}{c}\text { Tourism } \\
\text { Village Type }\end{array}$ & $\begin{array}{l}\text { Typical } \\
\text { Village }\end{array}$ & $\begin{array}{c}\text { Main } \\
\text { Attractions }\end{array}$ & Main Tourism Activities & Agents Participation \\
\hline $\begin{array}{l}\text { Whole } \\
\text { village } \\
\text { tourism type }\end{array}$ & Shiliuhong Village & Shiliuhong village & $\begin{array}{l}\text { Settlement landscape, } \\
\text { agritainment, picking } \\
\text { fruits and vegetables, } \\
\text { and renting land. }\end{array}$ & $\begin{array}{c}\text { Government-led, } \\
\text { villagers-based, } \\
\text { enterprise participation. }\end{array}$ \\
\hline $\begin{array}{c}\text { Scenic } \\
\text { driving type }\end{array}$ & $\begin{array}{l}\text { Guantian } \\
\text { Village }\end{array}$ & Mulan Great Lake & $\begin{array}{l}\text { Ecological sightseeing, } \\
\text { leisure and } \\
\text { entertainment, } \\
\text { agritainment, Mulan } \\
\text { culture. }\end{array}$ & $\begin{array}{l}\text { Enterprise-led, } \\
\text { government-supported, } \\
\text { villagers' participation. }\end{array}$ \\
\hline Rural elite driving type & $\begin{array}{l}\text { Qunyi } \\
\text { Village }\end{array}$ & Lianghu farmstead & $\begin{array}{l}\text { Rural sightseeing, leisure } \\
\text { and entertainment, fruit } \\
\text { and vegetable picking, } \\
\text { agritainment. }\end{array}$ & $\begin{array}{c}\text { Enterprise-led, villagers' } \\
\text { participation, } \\
\text { government-based. }\end{array}$ \\
\hline Enterprise driving type & $\begin{array}{c}\text { Xihu } \\
\text { Village }\end{array}$ & $\begin{array}{l}\text { Ji'nong Farm } \\
\text { supermarket }\end{array}$ & $\begin{array}{l}\text { Rural sightseeing, leisure } \\
\text { and entertainment, fruit } \\
\text { and vegetable picking, } \\
\text { agritainment. }\end{array}$ & $\begin{array}{c}\text { Enterprise-led, villagers' } \\
\text { participation, } \\
\text { government-based. }\end{array}$ \\
\hline
\end{tabular}




\subsubsection{Consolidation and Transformation Stage of the Rural Tourism System (from 2016 to Now)}

Since 2016, the environmental system in which rural tourism developed has undergone major changes, which has greatly promoted the consolidation and transformation of the rural tourism destination system. First, the increase in national income and the improvement of the urban traffic environment have strongly stimulated the demand of tourists, and the scale of tourists, travel radius, travel frequency, and consumption level have been greatly improved (Figure 5). Second, the imbalance between urban and rural development has become prominent; the rural tourism industry has become an important path for the promotion of rural poverty alleviation, rural revitalization, and overall urban and rural development, and it has also entered the industrialization era [4]. Third, the implementation of rural land and homestead policies such as the "separation of land ownership, management, and contacting rights" has revitalized idle assets in rural areas, standardized the orderly transfer of land management rights and moderate commercial operation of homesteads, and promoted the influx of social capital into rural areas. In the demand environment, rural tourism has entered the postmodernism period, and while the market scale has been expanding, the consumption pattern has gradually shifted from sightseeing to leisure and holiday tourism; moreover, personalized and diversified tourism needs such as family parent-child tours, health tourism, rural holiday tours, and study tourism have emerged, paying more attention to the emotional appeal of "homesickness" in line with an aesthetic artistic conception [53]. In addition, in the post-epidemic period, tourism in the infringe of the city was more popular (Table 7).

Table 7. Multiple agents' behaviors at the consolidation and transformation stage of the rural tourism destination system.

\begin{tabular}{|c|c|}
\hline Agent & Adaptive Behaviors \\
\hline Government & $\begin{array}{l}\text { Since 2016, Wuhan City has opened the construction of beautiful countryside demonstration villages. In } \\
\text { 2017, the three projects of "citizens going to the countryside, rural elite returning home, and enterprises } \\
\text { prospering the countryside" were implemented. In 2018, the "Three-year Action Plan for Wuhan } \\
\text { Comprehensive Tourism (2018-2021)" and "Wuhan Rural Revitalization Strategic Plan (2018-2022)" were } \\
\text { formulated, and the construction of the "Flower Tour" project was continued. } \\
\text { From } 2018 \text { to 2020, rural tourism festivals were held for three consecutive years, rural tourist spots were } \\
\text { promoted; now, coupons that allow people to benefit from tourism will be distributed, and many measures } \\
\text { will be introduced to promote recovery after the epidemic. } \\
\text { The Fourth Ring Road around Wuhan is open to traffic; Circular tourism highways and regional tourism } \\
\text { greenways have been constructed. }\end{array}$ \\
\hline Enterprise & $\begin{array}{l}\text { Social capital has entered the countryside to build rural tourism resorts, agricultural sightseeing parks, and } \\
\text { village B\&Bs. } \\
\text { The action of "state-owned enterprises joining villages" has been carried out and the political and } \\
\text { industrial advantages of state-owned enterprises have been transformed into the kinetic energy and } \\
\text { efficiency of rural tourism industry development. }\end{array}$ \\
\hline Resident & $\begin{array}{l}\text { The number of rural land and houses transferred to enterprises or cooperatives has increased significantly. } \\
\text { Beautification of the village micro-landscape environment and the addition of the leisure and ornamental } \\
\text { functions of agritainment; } \\
\text { More citizens and outgoing rural talents have carried out tourism business activities and evolved into } \\
\text { bionic villagers. }\end{array}$ \\
\hline Visitor & $\begin{array}{l}\text { Short-distance travel is in demand; } \\
\text { The desire to return to the field is strong, and the forms of vacation, health tourism, and parent-child } \\
\text { tourism are prominent. } \\
\text { Attention has been paid to the emotional appeal of "homesickness" under an aesthetic artistic conception. }\end{array}$ \\
\hline
\end{tabular}

During this period, rural tourism gradually changed from "countryside tourism" to "village tourism" and from the construction of scenic spots to the construction of a comprehensive landscape. Enterprises, the government, and media agents combined nonrural elements that took from the aesthetic principles of rural pastoral elements and jointly constructed a "poetic dwelling" tag [46]. Tags act as an important gathering motivation 
in the construction of rural tourism products and the construction of tourism landscapes. Rural communities have gradually transformed from traditional basic services, such as catering and accommodation, to rural comprehensive leisure and holiday communities, becoming an important tourist attraction.

With the promotion of policies such as beautiful countryside construction, Three Rural Projects, and rural revitalization, the coordinated development of rural tourism and rural communities in Wuhan deepened. Combining tourism resource endowments with rural villages, beautiful countryside belts were built (Table 7). Government agents and experts jointly formulated tourism development plans for poor villages with good resource endowments, planned rural tourism products and images, created a characteristic village landscape, and formed an endogenous model from rural development to rural tourism.

The rapid growth of rural tourist flow has put forward a rigid demand for supporting reception service facilities. The construction of rapid transit, subway transit, and villagebay highways was accelerated, and the tourism transportation network became denser, which promoted the comprehensive development of rural tourism in Wuhan (Table 7). The internal transportation service capacity has been continuously upgraded. It laid a solid foundation for the development of self-driving tourism and individual travel, and it promoted the process of transforming rural tourists into rural communities.

Favorable policies drove the investment and construction of tourism projects of many large-scale enterprises. Rural tourism products and formats were more plentiful, which included rural complexes, vacation homestays, RV camps, shared homestays, and agedhealth tourism (Table 7). With the large-scale construction and investment in tourism projects, the trends of the big scale, the high quality, and the premiumization of the construction of tourism attractions emerged, gathering in Yunjia slow village, Flower expo township, Mulan flower park, Huazhao valley township, and so on (Table 8).

Table 8. Overview of some rural leisure and holiday communities in Wuhan.

\begin{tabular}{|c|c|c|c|c|}
\hline Project & Village & Main Model & Opening Time & $\begin{array}{l}\text { Transfer Land } \\
\text { from Villages }\end{array}$ \\
\hline Husiguo township & Haiyang village & $\begin{array}{c}\text { Vacation homestay and leisure } \\
\text { agriculture }\end{array}$ & 2019 & 3200 acre \\
\hline $\begin{array}{l}\text { Flower expo } \\
\text { township }\end{array}$ & Tianxing village & Vacation homestay and $4 \mathrm{~A}$ scenic spot & 2017 & $1800 \mathrm{mu}$ \\
\hline Mulan flower park & Dutang village & Vacation homestay and $4 \mathrm{~A}$ scenic spot & 2017 & $7000 \mathrm{mu}$ \\
\hline $\begin{array}{l}\text { Fengxiang holiday } \\
\text { village }\end{array}$ & Liaoyuan village & $\begin{array}{c}\text { Vacation homestay and leisure } \\
\text { agriculture }\end{array}$ & 2020 & $6000 \mathrm{mu}$ \\
\hline Yunjia slow village & Qunyi village & $\begin{array}{c}\text { Vacation homestay and leisure } \\
\text { agriculture }\end{array}$ & 2020 & $4000 \mathrm{mu}$ \\
\hline $\begin{array}{l}\text { Huazhao valley } \\
\text { township }\end{array}$ & Luo Yang village & $\begin{array}{c}\text { Vacation homestay and leisure } \\
\text { agriculture }\end{array}$ & 2017 & $3500 \mathrm{mu}$ \\
\hline
\end{tabular}

With the maturation of rural tourism development, villagers acquired a strong desire to participate in rural tourism, and the capitalization of idle land and houses was accelerated. Attention was given to the construction of community landscapes, which promoted the tourism development of rural community space and accelerated the process of tourism "space production". The native villagers participated extensively through the establishment of farmers and cooperatives, farmers and enterprises, and other ways to enhance the management level of agritainment. Bionic villagers, such as talented rural people and foreign investors in cities and towns, participated in rural tourism management or project construction [54]. At the end of 2016, a total of 4029 elite people returned to their villages to start businesses, and 515 capable people engaged in the tertiary industry of rural sightseeing and tourism. They promoted the further improvement of tourism service facilities and promoted rural culture renewal. New forms of rural tourism such as B\&Bs, cultural and creative industries, art, main exhibition halls, and characteristic towns also emerged. At this time, the rural tourism community has been reconstructed drastically, from a traditional 
production and living space to a production, living, and leisure-consumption space that is shared by urban and rural residents.

\subsection{Co-Evolution of the Rural Tourism Destination System in Wuhan}

An analysis of the Wuhan rural tourism system processes suggests that the destination system has experienced the embryonic, formation, rapid development as well as consolidation and transformation periods, with various coexisting and interacting external environments, multiple agents, and system evolution (Table 9). Complex changes in the external industrial environment, economic environment, and tourists' demands have promoted the emergence of multiple agents, and the scale, types, and quantity of adaptive agents have obviously increased. The frequency and intensity of nonlinear interactions between agents and the environment were greatly enhanced. The numbers and combination models of "building blocks" such as tourist attractions and tourist facilities were more diverse, which co-promoted the increase in the number, rich formats, and perfect functions of the rural tourism system [55].

In the embryonic stage, the endowment of ecological resources became the initial driving force for the development of rural tourism. Rural tourist attractions were singular, with fewer tourists, and tourist destinations were scattered (Figure 6).

During the formation stage of the system, the implementation of the Golden-week holiday and the improvement of the socio-economic level stimulated the tourism demand of urban residents and promoted the acceleration of the supply of rural tourist destinations. "Mulan Eight Scenic Spots" and some other ecological scenic spots became "tags", promoting the influx of tourists, the soundness of facilities, and the tourism participation of pioneer villages. Around the core scenic area, each district formed a number of core-periphery agglomeration areas of rural tourism (Figure 6).

In the rapid development stage, the continuous supply of diversified rural tourism destinations led to a rapid increase of rural tourists' flow. The process of tourism commercialization brought significant economic effects to rural areas, and the development of tourism industry became an important path for poverty alleviation in poor rural areas. The government issued a number of land and tax policies to encourage the construction of various agricultural parks, agritainments, and leisure farms. The habitat environment was also improved to provide tourists with a good travel experience. Major tourist traffic routes and express highways connecting urban and rural areas were constructed to increase the scale of passenger flow, material flow, and information flow between urban and rural areas. The optimization of the rural living environment and rural tourism industrial environment attracted capable people to return to hometowns and leased villagers' land in order to develop the rural tourism industry, which further promoted the prosperity of the rural tourism industry. The rural tourism spatial distribution presented a plate-based pattern, with key scenic spots as the leader, and leisure villa, leisure farmhouse, and agricultural tourism spots as the support (Figure 6).

In the stage of consolidation and transformation, rural tourism entered the postmodern period, and by this time, tourists' demand for leisure and vacation was obvious. In the context of the widening urban-rural development gap, there was a strong demand for the comprehensive revitalization of rural areas through the development of rural tourism. Rural idle land and houses have flowed into tourism enterprises on a large scale, building many agricultural parks, leisure farms, boutique homestays, etc., providing the diversification of tourism activities such as sightseeing tours, parent-child tours, vacation tours, RV tours, night tours, health and wellness tours, etc. The improvement infrastructure and service facilities drive capital flow, information flow, technology flow between urban and rural areas, tourist destinations, and multiple agents [4]. The diffusion effect of tourist destinations is obvious, and the rural tourism spatial agglomerations have evolved from "plate" to "global". It is worth mentioning that the outbreak of the novel Coronavirus pandemic in Wuhan in 2020 led to the stagnation of the development of the rural tourism industry. However, in the second half of 2020, the government released measures such 
as free tourism entrance tickets and subsidies for tourism companies, which strongly promoted the recovery of the rural tourism market.

Table 9. The co-evolution of the rural tourism system in Wuhan city.

\begin{tabular}{|c|c|c|c|c|c|}
\hline \multicolumn{2}{|c|}{ Elements } & Embryonic Stage & Formation Stage & Development Stage & $\begin{array}{c}\text { Consolidation and } \\
\text { Transformation Stage }\end{array}$ \\
\hline \multicolumn{2}{|c|}{$\begin{array}{l}\text { Dominant external } \\
\text { environment }\end{array}$} & $\begin{array}{l}\text { Abundant } \\
\text { ecological resource } \\
\text { endowment }\end{array}$ & $\begin{array}{l}\text { Golden Week } \\
\text { holiday; Increased } \\
\text { economic level; } \\
\text { Rural tourism } \\
\text { demand for nature }\end{array}$ & $\begin{array}{l}\text { Ecological } \\
\text { civilization } \\
\text { construction; High } \\
\text { rural tourism } \\
\text { demand }\end{array}$ & $\begin{array}{l}\text { Internal needs for rural } \\
\text { revitalization; Post-modern } \\
\text { tourism; Post-epidemic period }\end{array}$ \\
\hline \multirow{7}{*}{$\begin{array}{l}\text { Agents } \\
\text { adaptive } \\
\text { behavior }\end{array}$} & Government & Tourism planning & $\begin{array}{l}\text { Formulate tourism } \\
\text { industry standards } \\
\text { and improve road } \\
\text { infrastructure }\end{array}$ & $\begin{array}{l}\text { Rural tourism } \\
\text { planning; Encourage } \\
\text { tourism } \\
\text { development; Land } \\
\text { policies reform }\end{array}$ & $\begin{array}{l}\text { Beautiful Countryside } \\
\text { Construction; Rural } \\
\text { revitalization planning; Three } \\
\text { Township Engineering (Three } \\
\text { Township Engineering: } \\
\text { Citizens go to the countryside; } \\
\text { Capable people return } \\
\text { countryside; Township } \\
\text { enterprises construct } \\
\text { countryside); Recovery of } \\
\text { rural tourism }\end{array}$ \\
\hline & Enterprise & $\begin{array}{l}\text { Construct } \\
\text { healthcare hotel for } \\
\text { employees }\end{array}$ & $\begin{array}{l}\text { Construct } \\
\text { ecological } \\
\text { sightseeing spot }\end{array}$ & $\begin{array}{l}\text { Construct } \\
\text { agricultural park, } \\
\text { leisure, and } \\
\text { entertainment scenic } \\
\text { spots }\end{array}$ & $\begin{array}{l}\text { Construct agricultural park, } \\
\text { leisure and entertainment } \\
\text { scenic spots, rural resort area }\end{array}$ \\
\hline & Villager & $\begin{array}{l}\text { Less involved in } \\
\text { rural tourism }\end{array}$ & $\begin{array}{l}\text { More involved in } \\
\text { rural tourism }\end{array}$ & $\begin{array}{l}\text { More involved in } \\
\text { rural tourism; Grant } \\
\text { of idle land }\end{array}$ & $\begin{array}{l}\text { More involved in rural } \\
\text { tourism; Grant of idle land } \\
\text { and house }\end{array}$ \\
\hline & Tourist & Few & Increasing & Rapidly increasing & Steadily increasing \\
\hline & $\begin{array}{l}\text { Returning } \\
\text { villager }\end{array}$ & Few & $\begin{array}{l}\text { Run agritainment } \\
\text { activities }\end{array}$ & $\begin{array}{l}\text { Lease land; Run the } \\
\text { agritainment } \\
\text { activities and } \\
\text { tourism farm }\end{array}$ & $\begin{array}{l}\text { Lease land and house; Run } \\
\text { the agritainment, homestay, } \\
\text { tourism farm }\end{array}$ \\
\hline & Association & -- & Few & Increasing & Increasing \\
\hline & Citizen & -- & -- & - & $\begin{array}{l}\text { Run a homestay; Hold art } \\
\text { activities }\end{array}$ \\
\hline \multirow{4}{*}{$\begin{array}{l}\text { Rural } \\
\text { tourism } \\
\text { system }\end{array}$} & $\begin{array}{l}\text { Tourism } \\
\text { product }\end{array}$ & $\begin{array}{l}\text { Few; Mainly } \\
\text { conference tourism } \\
\text { products }\end{array}$ & $\begin{array}{l}\text { Slowly increasing; } \\
\text { Mainly ecological } \\
\text { tourism products }\end{array}$ & $\begin{array}{l}\text { Rapidly increasing, } \\
\text { Mainly agricultural } \\
\text { leisure tourism } \\
\text { products }\end{array}$ & $\begin{array}{l}\text { Steady increase; Diverse } \\
\text { tourism products }\end{array}$ \\
\hline & $\begin{array}{l}\text { Service } \\
\text { facility }\end{array}$ & Few farmhouses & $\begin{array}{l}\text { Few farmhouses } \\
\text { and budget hotels }\end{array}$ & $\begin{array}{l}\text { More farmhouses } \\
\text { and budget hotels }\end{array}$ & $\begin{array}{l}\text { More resort hotels and } \\
\text { boutique homestays }\end{array}$ \\
\hline & Infrastructure & $\begin{array}{l}\text { Mainly urban } \\
\text { roads }\end{array}$ & $\begin{array}{l}\text { Mainly tourism } \\
\text { roads }\end{array}$ & $\begin{array}{l}\text { Mainly tourism } \\
\text { roads, rural trunk } \\
\text { roads }\end{array}$ & $\begin{array}{l}\text { Mainly tourism roads, rural } \\
\text { internal roads }\end{array}$ \\
\hline & $\begin{array}{l}\text { Spatial } \\
\text { pattern }\end{array}$ & $\begin{array}{l}\text { Scattered } \\
\text { distribution }\end{array}$ & $\begin{array}{l}\text { Multi-core cluster } \\
\text { distribution }\end{array}$ & $\begin{array}{l}\text { Multi-sector network } \\
\text { distribution }\end{array}$ & $\begin{array}{l}\text { Comprehensive tourism } \\
\text { distribution }\end{array}$ \\
\hline
\end{tabular}

In conclusion, the evolution of Wuhan rural tourism is characterized by nonlinear dynamics because of various feedbacks and self-reinforcing interactions amongst agents and the external environment. Although there are a variety of possible evolutionary trajectories and unpredictable change processes, the macro evolution trend of continuous 
development is certain. Adaptive and co-evolutionary mechanisms of agents, the external environment, and the rural system make it difficult for an individual element to initiate a radical change in destination development [12]. The future evolution of Wuhan rural tourism will still be driven by both macro-scale structural changes interacting with the micro-scale behavior of multi-agents (Figure 6).

\section{Conclusions and Discussion}

\subsection{Conclusions}

Based on the theory of a complex adaptive system, this paper constructed the theoretical framework of the system evolution of rural tourism destinations, performed an empirical case study on Wuhan, and discussed the adaptive behavior of multiple agents and their responses to the system evolution of rural tourism destinations under the disturbance of the external environmental state in different periods.

(1) Under the CAS theory system, the rural tourism destination system is composed of adaptive multi-agents, rural tourism attractions, rural tourism facilities, rural tourism communities, the external environment, and other subsystems. Rural tourism facilities, tourism attractions, tourism enterprises, tourism agents, etc., based on tagging mechanism agglomerated at high-quality tourism development locations. Governments, enterprises, villagers, tourists, and other agents had diversified adaptive behaviors to adapt to the new external environment, which were manifested in the formulation and implementation of planning and policies, the construction of various types of rural tourist destinations, the improvement of tourism infrastructure and service facilities, the development and transformation of rural tourism communities, the increase or decrease of tourist flow, etc., and then further feedback to the external environment. Through the interaction of nonlinear material, energy, and information, new spatial clusters of different levels, scales, and types were formed, and the internal elements, structures, and functions of the subsystems were constantly copied, reorganized, gathered, and differentiated, thus realizing the orderly leap of the rural tourism destination system.

(2) The evolutionary process of the rural tourist destination system in Wuhan went through the embryonic stage (before 2000), the formation stage (2001-2007), the rapid development stage (2008-2015), and the consolidation transition stage (since 2016). In the embryonic stage of the system, the interaction among enterprises, government, residents, tourists, and nongovernmental organizations was limited, rural tourism depended on the original resource endowment, and there were few infrastructure and service facilities. Around the mountains and lakes, many scattered holiday products were formed. In the system formation period, with the ever-increasing social and economic level and the implementation environment of the Golden Week holiday system, the government and enterprise agents played leading roles, made clear the development direction of rural ecotourism, improved infrastructure and service facilities, and attracted other enterprises, residents, and passengers to gather. A spatial agglomeration pattern with the key scenic spots of the Mulan Series as its core was formed. In the period of the rapid development of the system, the construction of an ecological civilization, the promotion of the industrial status, and the diversification of market demand greatly increased the number and scale of adaptive agents, and the nonlinear interaction was further enhanced. The government optimized the tourism development environment through industrial planning and policy support to promote the high-quality, branded, and large-scale development of the tourism industry. The tag of the leisure agriculture projects for Flower Viewing encouraged enterprises and villagers to play more active roles and sped up the construction of tourist attractions and facilities. The product system was oriented by key scenic spots that were supported by leisure villas, leisure farmhouses, and agricultural scenic spots. The gradual transformation of the rural community into a tourism consumption space attracted more tourists into the countryside and promoted the development of rural tourism plates. In the period of consolidation and transformation, the flow of creativity, capital, technology, passenger, and other elements between urban and rural areas in Wuhan accelerated, and the intensity and 
complexity of the interaction between multiple agents and the external environment was enhanced. The leading tag of "homesickness" led to the emergence of new participants and system elements, structures, and functions. The development mode of rural tourism has changed from "countryside tourism" to "village tourism", and the comprehensive tourism pattern has gradually become apparent.

\subsection{Discussion}

\subsubsection{Theoretical Implications}

(1) This article enriches the research paradigm of the tourism complex system. In the traditional view, the complexity of a system mainly comes from the outside. With the deepening of the research on tourism destination systems, there exist various examples of the butterfly effect, repeating patterns, bifurcation, strange attractions, self-organization, and emergence occurring and reoccurring over the years [15]. Based on CAS, we put forward a cyclic feedback model of the complex system of rural tourism, namely "environment state-agent behavior-system evolution", to deal with challenges in rural tourism system research. These include the need to take a holistic view of the nonlinear interacting agents across the rural tourism system. Agents face different environments at different development stages, and they will show different adaptive behaviors, causing movements in individual niche, and then driving the evolution of the system. Tourism enterprises, rural residents, tourists, governments, and other non-governmental organizations are affected by the environment and interact with each other. They gather or diffuse in a certain space, and perform diverse tourism participation behaviors, promoting the formation of tourism agglomerations of different activities, scales, and functions and driving the co-evolution of the overall rural system hierarchically. This bottom-up methodological thinking helps analyze the interrelationships and conversions between hierarchies and scales in the tourism spatial structure.

(2) Strengthens the research on the agent's adaptive ability and adaptive behavior in the evolution of the rural tourism destination system. Three very important core concepts, resilience, and vulnerability adaptability have been put forward in the Human Factors Plan for Global Environmental Change (IHDP), but there is a lot of research on resilience and vulnerability in the current academic research [56]. Compared with other tourism destination systems, the rural tourism destination system is highly dependent on community participation and rural residents [57]. The complexity level, spatial evolution, and sustainable development of the rural tourism system are derived from the transformation of the agents' adaptation behavior in time and space. Capital assets, experience, and knowledge, learning capabilities, social relations, and organizational regulation are all agents' resource reserves. Agents holding different resources have complex and diverse adaptation behaviors. When interacting with the external environment and other agents, they adjust and adapt strategies in a certain geographical space and store them in their own resource fountain to strengthen or change adaptive behavior further. Therefore, in the research of rural tourism destination system, we should fully understand the role and mechanism of "agents" in constructing and transforming the system

\subsubsection{Managerial Implications}

(1) Improves the self-adaptive level of rural tourism with system subjects. There are many subjects involved in the Wuhan rural tourism destination system, so it is necessary to improve the adaptive ability of stakeholders from different levels and perspectives [36]. Villagers are the core subjects of the rural tourism destination system, and they constantly improve the level and ability of tourism management in order to cope with various risks and challenges. The government should focus on optimizing guiding and regulating ability, standardizing the production behavior of various business entities, and strengthening the construction of tourism infrastructure and service facilities. While pursuing economic benefits, tourism enterprises should not neglect the protection of the ecological environment, 
rural landscape, and rural culture, and also enhance co-operation with villagers and rural associations.

(2) Actively responds to the transformation of the Wuhan rural tourism system under the situation of a normalized epidemic. At present, the situation of the COVID-19 epidemic is sporadic and weak in China. Normalized epidemic prevention and control forces the development of rural tourist destinations to face great pressure. Agents should adjust tourism participation and business behavior in time according to the environmental state and enhance its resilience to better adapt to environmental development. For example, by strengthening the level of regional tourism cooperation, speeding up the digital construction of tourism, increasing medical care, health care, and ecological tourism activities, and building a high-quality tourism service system.

\subsubsection{Limitations and Future Research Prospects}

CAS has a rich theoretical system for a complex adaptive system, including the classification and action mechanism of identification, the emergence caused by echo, genetic algorithm simulation, and so on. This paper only performs an exploratory and framework research to explore the adaptive behavior of rural tourism subjects affected by environmental conditions in different development periods, and the evolutionary effects of rural system elements, structures, functions, and spatial patterns brought about by them. Further research is still needed in many aspects.

(1) Tagging is an important mechanism of agent interaction, which can be further divided into offensive tags, defensive tags, and so on. What are the respective tags of the agents in the rural tourism destination system, and how do they adhere, evolve, or reproduce? (2) What differences are there between evolution and the evolutionary mechanism of rural tourism destinations with different development models and different scales, and what are the complex adaptation mechanisms in the evolutionary process. (3) How to quantitatively measure the adaptability of each subject to complex environments and challenges, and determine what role it has played in the resilience and sustainable development of the rural tourism community. (4) How to combine the CAS genetic algorithm with ABM, use simulation methods to model and predict the evolution of tourism system, and manage the operation of tourism destination. (5) Research on the combination of the complex adaptive system method and other complexity research methods.

Author Contributions: Conceptualization, L.L. and J.H.; methodology, L.L.; software, X.X.; validation, X.X., L.L. and X.T.; formal analysis, L.L.; investigation, X.X.; resources, X.T.; data curation, X.X. and X.T.; writing—original draft preparation, L.L.; writing—review and editing, J.H.; visualization, L.L.; supervision, J.H. All authors have read and agreed to the published version of the manuscript.

Funding: This research was funded by the Philosophy and Social Science Foundation of MOE of China (grant number 11JBGP041), Humanities and Social Science Project of Fuyang normal university (grant number 2021FSSK14ZD).

Institutional Review Board Statement: Not applicable.

Informed Consent Statement: Not applicable.

Data Availability Statement: Not applicable.

Acknowledgments: The authors thank Zhongyuan Zhu, Yanyang Yang, Haimeng Liu, Jingyu Chen, HongJing Xie, Bo Liu, and some other classmates for their help during the data collection and curation phases of the project.

Conflicts of Interest: The authors declare no conflict of interest.

\section{References}

1. Rosalina, P.D.; Dupre, K.; Wang, Y. Rural Tourism: A Systematic Literature Review on Definitions and Challenges. J. Hosp. Tour. Manag. 2021, 47, 134-149. [CrossRef]

2. Huang, Z.F.; Lu, L.; Su, Q.; Zhang, J.; Sun, J.; Wan, X.; Jin, C. Research and Development of Rural Tourism under the Background of New Urbanization: Theoretical Reflection and Breakthrough of Predicament. Geogr. Res. 2015, 34, 1409-1421. 
3. Su, B. Rural Tourism in China. Tour. Manag. 2011, 32, 1438-1441. [CrossRef]

4. Lu, L.; Ren, Y.S.; Zhu, D.C. The Research Framework and Prospect of Rural Revitalization Led by Rural Tourism. Geogr. Res. 2019, 38, 102-118.

5. Yang, J.; Yang, R.X.; Chen, M.H.; Su, C.H.J.; Zhi, Y.; Xi, J. Effects of Rural Revitalization on Rural Tourism. J. Hosp. Tour. Manag. 2021, 47, 35-45. [CrossRef]

6. Tao, Y.X. An Empirical Study of the Demand Mechanism and Appeals-Alienation of Rural Tourism. Tour. Trib. 2015, 30, 37-48.

7. Kim, S.; Jamal, T. The Co-Evolution of Rural Tourism and Sustainable Rural Development in Hongdong, Korea: Complexity, Conflict and Local Response. J. Sustain. Tour. 2015, 23, 1363-1385. [CrossRef]

8. Chen, J.; Yang, X.J.; Wen, X.; Deng, M. The Theoretical Framework and Demonstration of Rural Adaptive Evolution in the Context of Tourism Development. J. Nat. Resour. 2020, 23, 1363-1385.

9. Lu, L.; Zhang, Q.Y.; Huan, J.F.; Ren, Y.S. A Theoretical Research and Prospect of Tourism Destination Evolution Based on a Glocalization Perspective. Acta Geogr. Sin. 2021, 76, 1504-1520.

10. Leiper, N. The Framework of Tourism. Ann. Tour. Res. 1979, 64, 390-407. [CrossRef]

11. Butler, R.W. The Concept of a Tourist Area Cycle of Evolution Implications for Management of Resources. Can. Geogr. 1980, 24, 5-12. [CrossRef]

12. Ma, M.; Hassink, R. An Evolutionary Perspective on Tourism Area Development. Ann. Tour. Res. 2013, 41, 89-109. [CrossRef]

13. Faulkner, B.; Russell, R. Chaos and Complexity in Tourism: In Search of a New Perspective. Pac. Tour. Rev. 1997, 1, 93-102.

14. Baggio, R. Oriental and Occidental Approaches to Complex Tourism Systems. Tour. Plan. Dev. 2013, 10, 217-227. [CrossRef]

15. Speakman, M. A Paradigm for the Twenty-First Century or Metaphorical Nonsense? The Enigma of Complexity Theory and Tourism Research. Tour. Plan. Dev. 2017, 14, 282-296. [CrossRef]

16. Baggio, R. Symptoms of Complexity in a Tourism System. Tour. Anal. 2008, 13, 1-20. [CrossRef]

17. Mckercher, B. A Chaos Approach to Tourism. Tour. Manag. 1999, 20, 425-434. [CrossRef]

18. McDonald, J.R. Complexity Science: An Alternative World View for Understanding Sustainable Tourism Development. J. Sustain. Tour. 2009, 17, 455-471. [CrossRef]

19. Russell, R.; Faulkner, B. Entrepreneurship, Chaos and the Tourism Area Lifecycle. Ann. Tour. Res. 2004, 31, 556-579. [CrossRef]

20. Speakman, M.; Díaz Garay, A. Perspectives on Tourism Development Planning in Acapulco: Conventional Methods and Complexity Theory. Int. J. Tour. Sci. 2016, 16, 203-221. [CrossRef]

21. Zhang, S.L.; Zou, Z.J. Tourism Planning Synthetic Integrated Methodology Dealing with the Open Complicated and Large System. Hum. Geogr. 2001, 16, 11-15.

22. Hartman, S. Towards Adaptive Tourism Areas? A Complexity Perspective to Examine the Conditions for Adaptive Capacity. J. Sustain. Tour. 2016, 24, 299-314. [CrossRef]

23. Iandolo, F.; Fulco, I.; Bassano, C.; D’Amore, R. Managing a Tourism Destination as a Viable Complex System. The Case of Arbatax Park. Land Use Policy 2019, 84, 21-30. [CrossRef]

24. Harris, D.L. Echo Implemented: A Model for Complex Adaptive Systems Computer Experimentation; Office of Scientific \& Technical Information Technical Reports, University of North Texas: Denton, TX, USA, 2001.

25. Lu, L.; Bao, J. The Course and Mechanism of Evolution about Qiandao Lake:Based on the Theory of Dissipative Structure. Acta Geogr. Sin. 2010, 65, 755-768.

26. Ying, X. On the Regional Implosion of Tourist Flows: From Self -Organization to Organization. Tour. Trib. 2006, $26,47-54$.

27. Baggio, R.; Scott, N.; Cooper, C. Network Science. A Review Focused on Tourism. Ann. Tour. Res. 2010, 37, 802-827. [CrossRef]

28. Yang, Z.Y.; Yin, M.; Xu, J.G.; Lin, W. Spatial Evolution Model of Tourist Destinations Based on Complex Adaptive System Theory:A Case Study of Southern Anhui, China. J. Geogr. Sci. 2019, 29, 1411-1423. [CrossRef]

29. Sessa, L. The Science of Systems for Tourism Development. Ann. Tour. Res. 1988, 2, 219-235. [CrossRef]

30. Yang, C.Y.; Huang, Z.F.; Mao, W.D. On the Schools, Courses and Prospect of Complex System Evolution Theory in Tourism Areas. Hum. Geogr. 2009, 24, 66-70.

31. Yang, C.Y.; Huang, Z.F.; Mao, W.D. Research on Fundamental Issues of Tourism Region Complex System Evolution Theory. China Popul. Resour. Environ. 2009, 19, 123-130.

32. Holland, J. Emergence from Chaos to Order; Basic Books: New York, NY, USA, 1999.

33. Holland, J. Hidden Order: How Adaptation Builds Complexity; Basic Books: New York, NY, USA, 1996.

34. Stevenson, N.; Airey, D.; Miller, G. Complexity Theory and Tourism Policy Research. Int. J. Tour. Policy 2009, 2, 206-220. [CrossRef]

35. Chen, Y. Complex Adaptive System Theory and Its Application: Foundation, Contents and Implication. J. Syst. Dialectics 2001, 9 , 35-39.

36. Li, B.H.; Zeng, R.Q.; Liu, P.L. Human Settlement Evolution of Traditional Village Based on Theory of Complex Adaptive System: A Case Study of Zhangguying Village. Geogr. Res. 2018, 37, 1982-1996.

37. Zheng, W. Research Progress and Development Trend in Urban Economic Network Study Based on Complexity Theory. Prog. Geogr. 2015, 34, 376-686.

38. Shi, Y.J.; Zhai, G.F.; Xu, L.H.; Zhou, S.T.; Lu, Y.W.; Liu, H.B.; Huang, W. Assessment Methods of Urban System Resilience: From the Perspective of Complex Adaptive System Theory. Cities 2021, 112, 103141. [CrossRef]

39. Zhu, A.H.; Wu, Y.P. Understanding Complexity Adaptive System and Enterprise Management Studying. Sci. Manag. Res. 2003, $23,63-66$. 
40. Jin, H.; Yi, R.; Wang, Y.M.; Zhou, H.B. Toward a Complex Adaptive System: The Case of the Zhongguancun Entrepreneurship Ecosystem. J. Bus. Res. 2021, 128, 537-550. [CrossRef]

41. Hu, W.J.; Chen, Y. Study on the Evolvement Route of Innovation Cluster Based on CAS Methodology. Complex Syst. Complex. Sci. 2008, 5, 22-27.

42. Zeng, Z.X.; Zhang, Y.F.; Li, M. Research on Collaborative Governance Mechanism of Supply Chain Social Responsibility Based on CAS Theory. J. Syst. Sci. 2020, 28, 71-77.

43. Choi, T.Y.; Dooley, K.J.; Rungtusanatham, M. Supply Networks and Complex Adaptive Systems: Control versus Emergence. J. Oper. Manag. 2001, 19, 351-366. [CrossRef]

44. Phillips, M.A.; Ritala, P. A Complex Adaptive Systems Agenda for Ecosystem Research Methodology. Technol. Forecast. Soc. Chang. 2019, 148. [CrossRef]

45. Bone, C. A Complex Adaptive Systems Perspective of Forest Policy in China. Technol. Forecast. Soc. Chang. 2016, 112, 138-144. [CrossRef]

46. Zhang, L.; Wu, Y. The Formatting Mechanism of Tourism Cluster Based on CAS Theory: Taking Mice Tourism Cluster in Guangzhou as a Case. Econ. Geogr. 2013, 33, 171-176.

47. Baggio, R. The Science of Complexity in the Tourism Domain: A Perspective Article. Tour. Rev. 2019, 75, 16-19. [CrossRef]

48. Yang, C.Y.; Huang, Z.F.; Mao, W.D. A Preliminary Discussion about the Evolutionary Mechanism of Tourism Destinations Based on System Science. Tour. Trib. 2009, 24, 55-62.

49. Shu, X.L.; Gao, Y.B.; Zhang, Y.X. Study on the Coupling Relationship and Coordinative Development between Tourism Industry and Eco-Civilization City. China Popul. Resour. Environ. 2015, 25, 82-90.

50. Huang, J.; Lu, L. The Paradigm Transformation of Space in Tourism Destination from Perspective of Production of Space: A New Paradigm of Space Based on Emergence of Space. Sci. Geogr. Sin. 2015, 35, 47-55.

51. Deng, A. Research on the In-Depth Expansion of the Rural Leisure Tourism Product System in Wuhan. Agric. Econ. Issues 2011, 10, 66-70.

52. Wei, C.; Ge, D.; Long, H. The Tourism-Led Rural Transformation Development Mode in the Metropolitan Fringe Region: The Case of Wuhan City. Econ. Geogr. 2018, 38, 211-217.

53. Panzer-Krause, S. The Lost Rural Idyll? Tourists' Attitudes towards Sustainability and Their Influence on the Production of Rural Space at a Rural Tourism Hotspot in Northern Ireland. J. Rural Stud. 2020, 80, 235-243. [CrossRef]

54. Sheng, Y.; Liu, Q. The Evolution of Human-Land Relationship in the Transmutation Process of Rural Tourism in Traditional Villages in Suburban Cities: A Case Study of Xunlonghe Village. Tour. Trib. 2021, 36, 95-108.

55. Garrod, B.; Wornell, R.; Youell, R. Re-Conceptualizing Rural Resources as Countryside Capital: The Case of Rural Tourism. J. Rural Stud. 2006, 22, 117-128. [CrossRef]

56. Janssen, M.A.; Schoon, M.L.; Ke, W.; Börner, K. Scholarly Networks on Resilience, Vulnerability and Adaptation within the Human Dimensions of Global Environmental Change. Glob. Environ. Chang. 2006, 16, 240-252. [CrossRef]

57. Wu, M.-Y.; Wu, X.; Li, Q.-C.; Tong, Y. Community Citizenship Behavior in Rural Tourism Destinations: Scale Development and Validation. Tour. Manag. 2022, 89, 104457. [CrossRef] 